\title{
Digital monitoring of agro-ecosystems indicators on the basis of space and unmanned technologies
}

\author{
Oleg Olenin ${ }^{1, *}$, Sergey Zudilin ${ }^{1}$, Yuriy Osorgin ${ }^{1}$, Sergey Shevchenko ${ }^{2}$, and Alexander Chernov $^{3}$ \\ ${ }^{1}$ Samara State Agrarian University, 446442 Kinel, Samara region, Russia \\ ${ }^{2}$ Samara Scientific Research Agricultural Institute named after N. Tulaikov, 446254 Bezenchuk district, Samara region, Russia \\ 3 “GIS-R" Ltd., Apt. 57, 443081 Samara, Russia
}

\begin{abstract}
The aim of the research is to develop a digital monitoring methodology for agro-ecosystem indicators based on space and unmanned technologies with the conversion of digital aerial photography results into real parameters of agrophytocenosis indicators as physical units. The paper uses the results of research on digital monitoring of agrophytocenosis of single- and poly-species crops of grain and leguminous crops on the experimental field of the Samara State Agrarian University in 2018 (southern forest-steppe of Trans-Volga region). The soil is a typical medium heavy black loamy chernozem (humus content is $5.9 \%$, easily hydrolysed nitrogen is $80-120 \mathrm{mg} / \mathrm{kg}$, labile phosphorus is $135-145 \mathrm{mg} / \mathrm{kg}$, exchangeable potassium is $150-195 \mathrm{mg} / \mathrm{kg}$, salt extract $\mathrm{pH}$ is 6.9 ). The research conducted in 2018 revealed that the stated aim is achievable in principle. According to the results of 2018, the greatest correlation between the vegetative biomass index NDVI and grain yield for winter and spring cereal crops was detected at the milky stage of the grains (up to $r=0.82$ ).
\end{abstract}

\section{Introduction}

In 2018, the national project "Digital Economy" was adopted in Russia at the national legislative level. It was one of thirteen Russian national projects for the period from 2019 to 2024 (the passport of the project was approved by the decision of the Presidium of the Presidential Council on Strategic Development and National Projects on December 24, 2018) [1].

The national project "Digital Economy" was created to solve, among others, the following problems: the transformation of priority sectors of the economy and social sphere, including health care, education, industry, agriculture, building construction, urban economy, transport and energy infrastructure, financial services, through the introduction of digital technology and platforms. Thus, the digital transformation of the agroindustrial complex becomes a priority for state authorities, research institutions and agrarian educational institutions [2].

Development of space and unmanned technologies, unmanned aircraft systems (UAS) and special software (including platform solutions) in agriculture and crop production will allow increasing mobility, efficiency and quality of monitoring indicators of agroecosystems and associated natural ecosystems in the framework of adaptive landscape agriculture as a whole [3-8].

The following areas are the most promising for the use of unmanned aerial photography: building digital elevation models, analyzing the heterogeneity of soil fertility by spectral characteristics, monitoring work in the fields, assessing crop variability by vegetation indexes, thermal maps of crops, identifying damage to vegetation from external influences [3, 4].

Digital monitoring of agroecosystem indicators is carried out on the basis of assessment of crop variability by vegetation indexes, using aerial photographs on a multispectral camera.

Having the data of multispectral photography, we can calculate a variety of vegetation indexes: Normalized Difference Vegetation Index (NDVI), which allows to conduct the qualitative and quantitative assessment of the volume of biomass, to assess the intensity of plant vegetation; Enhanced Normalized Difference Vegetation Index (ENVI), which is similar to NDVI, but also uses part of the visible spectrum for more effective indication of plant health status; Green Normalized Difference Vegetation Index (GNDVI), which allows to assess the content of chlorophyll, the degree of aging, the presence of stress in the plant; Difference Vegetation Index (DVI), which allows you to determine areas of darkening, stagnation of water, soil and vegetation; Green Difference Vegetation Index (GDVI), which shows the amount of nitrogen in the leaves, which can optimize fertilizer application based on actual needs $[3,4]$.

Vegetation indexes give an overall picture of the status of certain indicators of agrophytocenosis, as they are relative values (for example, the values of the NDVI index from 0 to 1). However, for agricultural producers it is important to have specific data in physical terms, for example, the volume of biomass in the field or the potential crop productivity in tons per hectare.

Corresponding author: agrotonik63@mail.ru 
Key words: digital transformation of the agroindustrial complex, space and unmanned technologies, unmanned aircraft systems, digital monitoring of agroecosystem indicators, multispectral imaging, vegetation indexes, yield structure and crop productivity.

\section{Materials and methods}

\subsection{Study objectives}

Objectives of this work are: 1. Development of a methodology for using software and hardware for space and unmanned technologies and unmanned aircraft systems (UAS) for digital monitoring of agroecosystem indicators. 2. Development of a digital platform for online conversion of vegetation indexes into specific parameters of agrophytocenosis indicators in physical units (for example, $\mathrm{t} / \mathrm{ha}, \mathrm{mg} / \mathrm{kg}$ and others), applicable to different crops at different vegetation phases in curtain soil and climatic conditions.

Research tasks: 1. Monitoring the state of vegetation, using the high-resolution images at different stages of vegetation, obtained with the help of UAS, based on NDVI. 2. Monitoring of the landscape and geomorphological conditions (height above sea level, slope of the relief, exposure of the slopes). 3. Decryption of electronic maps of contamination of crops based on the biomass index. 4. Decryption of electronic maps of nitrogen content in plant crops based on biomass index. 5. Composition of thermomaps of crops based on thermal imaging in different vegetation phases and at different times of the day. 6. 3-D modeling of agrophytocenosis. 7. Predicting of yield potential based on NDVI.

\subsection{Methods of the research}

We performed digital monitoring using the method of obtaining high-resolution images at different crop vegetation stages using unmanned aircraft systems (UAS) using vegetation indexes, including the biomass index (NDVI). Indicators of agrophytocenosis in the form of field statistics were determined according to generally accepted methods based on national standard (GOST). The results of aerial photography were calibrated by the collected data of the field statistics of the relevant parts of experimental fields.

\section{Results}

Creating a digital platform to convert the results of various types of digital aerial photography into real physical indicators of crops depends directly on the degree of fullness of statistical databases. That is why the work on creating a platform is intended to continue for 3-4 years, as far as the collection and accumulation of field statistics on various crops is made.

In 2018, the laboratory "AgroEcology" at the Department of Land Management, Soil Science and Agrochemistry of the Samara State Agrarian University together with the company "GIS-R" Ltd. (Samara) conducted research in experimental fields on the following topic "The digital monitoring of agroecosystems indicators based on space and unmanned technologies as the basis of Digital Organic Farming", in accordance with the signed Contract N810/K/2018 dated 03.08.2018 [9].

The experimental plot is located in the central zone of the Samara oblast, in the southern forest-steppe of the Trans-Volga region. The soil of the experimental plot is a typical medium heavy black loamy chernozem (agrochemical parameters of the layer $0-40 \mathrm{~cm}$ : humus content is $5.9 \%$, easily hydrolyzed nitrogen is $80-120$ $\mathrm{mg} / \mathrm{kg}$, labile phosphorus is $135-145 \mathrm{mg} / \mathrm{kg}$, exchangeable potassium is $150-195 \mathrm{mg} / \mathrm{kg}$, salt extract $\mathrm{pH}$ is 6.9) (Fig. 1).

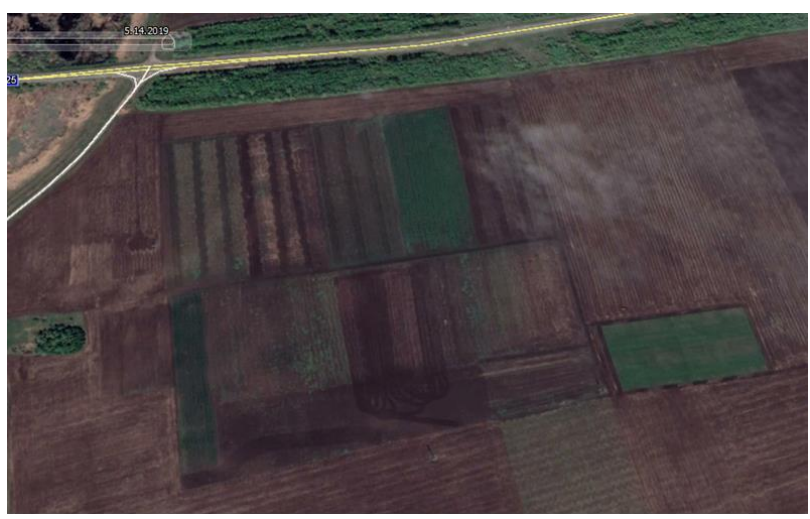

Fig. 1. Experimental plot of the laboratory "Agroecology" at the department of "Land management, soil science and agrochemistry" of the Samara State Agrarian University (American satellite system Google Earth, 05/14/2019)

The agrometeorological conditions of the agricultural year 2017-2018 can be characterized as not entirely favourable for the production of most field crops. The winter period was warmer than usual at $9.20^{\circ} \mathrm{C}$ and the precipitation level exceeded the average multiyear level by $137.4 \%$. May was arid with a precipitation of $20.7 \mathrm{~mm}$, which is 1.6 times lower than normal; July and August were warmer than usual at 3.1 and $1.40{ }^{\circ} \mathrm{C}$, respectively. The precipitation during the summer was extremely unequal: June and August were extremely dry with the amount of precipitation in these months 2.1 and 3.6 times lower than the multiyear average.

Studies were carried out in a multifactorial field stationary experiment in the fields of two six-field crop rotations with single-species and poly-species (mixed and joint) crops. Crop rotation 1 (control) as singlespecies crops: 1) black fallow; 2) winter wheat; 3 ) spring hard wheat; 4) peas; 5) barley; 6) sunflower. Crop rotation 2 as poly-species crops: 1) seeded fallow (yellow melilot Melilotus officinalis); 2) winter wheat + winter vetch (Vicia villosa); 3) spring hard wheat + barley + peas; 4 ) winter wheat + spring wheat + peas (spring sowing); 5) barley + peas; 6) sunflower + yellow melilot.

Multispectral and thermal imaging (early in the morning and in the afternoon) surveys were carried out 
on the fields that make up the polygon 2 (area is 4 hectares): field 1 - winter wheat; field 2 - winter wheat + winter vetch; field 3 - barley; field 4 - spring hard wheat + barley + peas (Fig. 2).

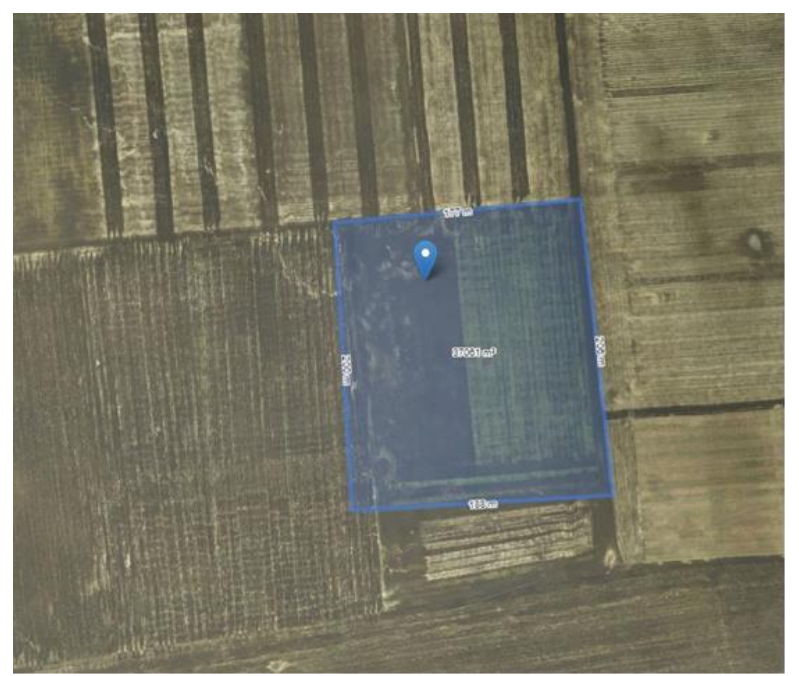

Fig. 2. Polygon 2, 4 hectares area

The obtained values of vegetation indexes and temperature (after processing of aerial photography materials by a special digital platform AgroGIS by "GISR" Ltd.) must be accompanied by field statistics data to accumulate a database. On the basis of this database a digital survey is to be developed, which can convert the results in the form of vegetation indexes in real physical indicators (optimally in the on-line mode) [9].

To accomplish the task of collecting field statistics, a preliminary methodology was developed, which will be adjusted in 2019:

1. In each field, nine typical plots of $1 * 1 \mathrm{~m}$ in size (area is $1 \mathrm{~m}^{2}$ ) are selected, significantly differing in the main indicators of agrophytocenosis (weed infestation, plant formation structure, pests and diseases). We place a marker in the centre of the plot: height is $1.50 \mathrm{~m}$, the upper part $(15 \mathrm{~cm})$ is coloured red, and a number is assigned (Fig. 3). The coordinates of the marker are determined by WGS84 satellite navigation.

2. The following observations were conducted at each plot on the day of the flight session (either for 1-2, or maximum 3 days after the session): number of plants of the certain crop/plant mass of crops/number of weeds/weight of weeds/species composition of weeds/height of plants and ear length/pests and diseases/tillering capacity/color and condition of plants/photo. The data were filled in special tables during the measurement process directly in the field.

3. After full maturity of the crop plants, they were collected completely (from one $\mathrm{m}^{2}$ ) in sheaves to process the yield structure, which was determined in the laboratory.

4. Collected field statistics were processed, systematized and accumulated in special tables in the form of databases.

5. The final stage of the work was binding of the collected field statistics to the results of imaging surveys (multispectral, thermal and optical).
According to coordinates on the electronic map, we determined the location of a specific marker, and then cut out a site around the marker, which was entered in a table with indicators of agrophytocenosis from this site.

As an example, we present the results of digital monitoring of field 2 (winter wheat + winter vetch) from polygon 2 .

Indicators of agrophytocenosis on nine markers were determined: May 19 (phase is tillering of winter wheat), June 14 (bloom) and June 25 (milk stage) and July 24 (full ripeness, 7 days before harvesting).

During each session, the structure of winter wheat and a separate winter vetch was determined. The data were entered into different tables for each culture, and then a single table for two crops of this field was composed according to the results of a specific session (Table 1).

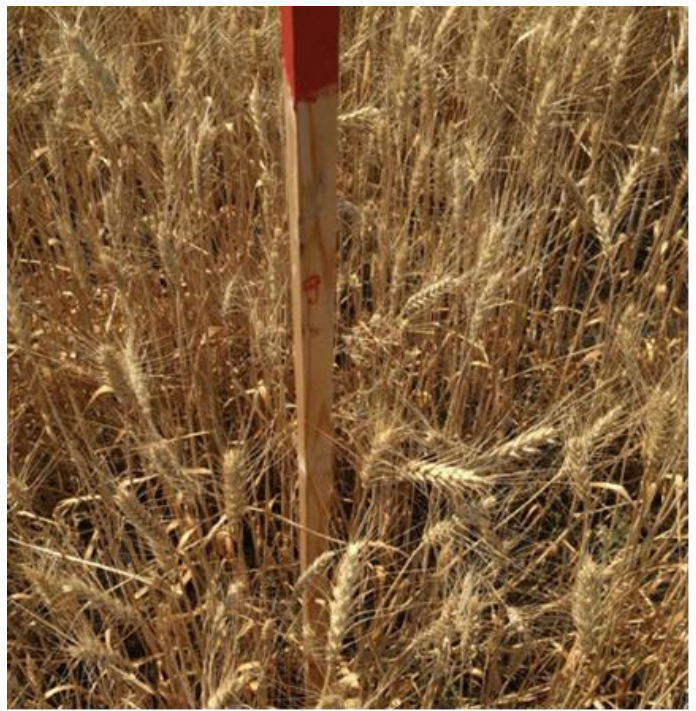

Fig. 3. Marker number 9, field 1, winter wheat, 07/24/2018

Later, based on the final tables of all aerial photography sessions (in this case, four dates), the final table of digital monitoring was compiled for this field (Table 2).

Field statistics, given in table 2, will serve as an integral part of the database, on the basis of which a digital platform will be developed to convert on-line vegetation indexes into specific physical parameters (in $\mathrm{t} / \mathrm{ha}, \mathrm{mg} / \mathrm{kg}$, etc.) of agrophytocenosis indicators for different crops in different vegetation phases in these soil - climatic conditions.

According to the statistical data of the final table 2, the correlation coefficients between the biomass, total and the biomass of the grain and NDVI were calculated.

Calculations has shown a high correlation of the NDVI with physical indicators of biomass for all dates of aerial photography. However, the maximum correlation was noted in the milky stage of winter wheat, that is, on the date of June 25. So, for NDVI from May 19 - biomass, total, t/ha $-\mathrm{r}=0.71$, biomass, grains, $\mathrm{t} / \mathrm{ha}-\mathrm{r}=0.79$, for NDVI from June 14 - biomass, total, $\mathrm{t} / \mathrm{ha}-\mathrm{r}=0.67$, biomass, grains, $\mathrm{t} / \mathrm{ha}-\mathrm{r}=0.70$, for NDVI from June 25 - biomass, total, $\mathrm{t} / \mathrm{ha}-\mathrm{r}=0.85$, biomass, grains, $\mathrm{t} / \mathrm{ha}-\mathrm{r}=0.82$. 
Table 1. Crop structure: field 2, winter wheat + winter vetch, 05/19/2018, tillering of winter wheat

\begin{tabular}{|c|c|c|c|c|c|c|c|c|c|}
\hline \multirow[t]{2}{*}{ Indicators } & \multicolumn{9}{|c|}{ Markers } \\
\hline & 1 & 2 & 3 & 4 & 5 & 6 & 7 & 8 & 9 \\
\hline \multicolumn{10}{|l|}{ NDVI } \\
\hline & $0.276 / 0.25$ & $0.323 / 0.3$ & $0.513 / 0.5$ & $0.673 / 0.6$ & $0.564 / 0.5$ & $\begin{array}{c}0.660 / 0 \\
6\end{array}$ & $0.342 / 0.3$ & $0.537 / 0.5$ & $0.630 / 0.6$ \\
\hline $\begin{array}{l}\text { Local } \\
\text { temperatur } \\
\mathrm{e},{ }^{\circ} \mathrm{C}\end{array}$ & 22.995 & 23.392 & 21.498 & 20.537 & 21.271 & 22.554 & 23.536 & 22.157 & 24.434 \\
\hline $\begin{array}{l}\text { Height } \\
\text { above the } \\
\text { sea level, } \\
\text { m }\end{array}$ & 38.30 & 38.27 & 38.23 & 38.30 & 38.21 & 38.19 & 38.16 & 38.25 & 38.50 \\
\hline $\begin{array}{l}\text { Number of } \\
\text { plants, } \\
\text { total, per } \\
\text { square m }\end{array}$ & 109 & 110 & 196 & 246 & 198 & 243 & 160 & 219 & 261 \\
\hline $\begin{array}{l}\text { Bushiness, } \\
\text { pcs. }\end{array}$ & \multicolumn{9}{|c|}{$3-5$} \\
\hline $\begin{array}{l}\text { Height of } \\
\text { the plants, } \\
\mathrm{cm} \text {, winter } \\
\text { wheat/wint } \\
\text { er vetch }\end{array}$ & $30 / 15$ & $37 / 43$ & $50 / 50$ & $58 / 53$ & $45 / 40$ & $58 / 55$ & $35 / 30$ & $40 / 35$ & $55 / 50$ \\
\hline $\begin{array}{l}\text { Color of } \\
\text { plants }\end{array}$ & Green & $\begin{array}{l}\text { Dark } \\
\text { green }\end{array}$ & $\begin{array}{l}\text { Dark } \\
\text { green }\end{array}$ & $\begin{array}{l}\text { Dark } \\
\text { green }\end{array}$ & Green & $\begin{array}{l}\text { Dark } \\
\text { green }\end{array}$ & Green & Green & $\begin{array}{l}\text { Dark } \\
\text { green }\end{array}$ \\
\hline $\begin{array}{l}\text { Number of } \\
\text { weeds, per } \\
\text { square } \mathrm{m}^{2}\end{array}$ & 14 & 17 & 16 & 9 & 15 & 7 & 70 & 24 & 11 \\
\hline $\begin{array}{l}\text { Weed } \\
\text { biomass, } \\
\mathrm{g} / \mathrm{m}^{2}\end{array}$ & 8.4 & 33.6 & 8.1 & 5.8 & 12.0 & 5.6 & 140.0 & 33.6 & 6.6 \\
\hline $\begin{array}{l}\text { Crop } \\
\text { biomass, } \\
\mathrm{g} / \mathrm{m}^{2}\end{array}$ & 607 & 950 & 3163 & 5242 & 3144 & 5148 & 816 & 1314 & 4750 \\
\hline $\begin{array}{l}\text { Crop } \\
\text { condition } \\
\text { (scale of } 5 \\
\text { points) }\end{array}$ & 1 & 3 & 4 & 5 & 3 & 5 & 2 & 3 & 4 \\
\hline $\begin{array}{l}\text { Species } \\
\text { compositio } \\
n \text { of weeds }\end{array}$ & $\begin{array}{c}\text { Chenopodiu } \\
\text { m album, } \\
\text { Panicum } \\
\text { crus-galli }\end{array}$ & $\begin{array}{c}\text { Convolvul } \\
\text { us } \\
\text { arvensis }\end{array}$ & $\begin{array}{l}\text { Chenopodiu } \\
\text { m album, } \\
\text { Convolvulu } \\
\text { s arvensis, } \\
\text { Polygonum } \\
\text { aviculare }\end{array}$ & $\begin{array}{l}\text { Chenopodiu } \\
\text { m album, } \\
\text { Convolvulu } \\
\text { s arvensis } \\
\text { Polygonum } \\
\text { aviculare }\end{array}$ & $\begin{array}{c}\text { Convolvul } \\
\text { us } \\
\text { arvensis } \\
\text { Polygonu } \\
m \\
\text { aviculare }\end{array}$ & $\begin{array}{c}\text { Polygonu } \\
m \\
\text { aviculare }\end{array}$ & $\begin{array}{l}\text { Chenopodiu } \\
\text { m album, } \\
\text { Convolvulu } \\
\text { s arvensis } \\
\text { Polygonum } \\
\text { aviculare, } \\
\text { Lamium }\end{array}$ & $\begin{array}{l}\text { Chenopodiu } \\
\text { m album, } \\
\text { Convolvulu } \\
\text { s arvensis, } \\
\text { Polygonum } \\
\text { aviculare }\end{array}$ & $\begin{array}{l}\text { Chenopodiu } \\
\text { m album, } \\
\text { Polygonum } \\
\text { aviculare }\end{array}$ \\
\hline $\begin{array}{l}\text { Coordinate } \\
\text { s } \\
\text { WGS } 84\end{array}$ & $\begin{array}{l}53.246111 \\
50.726944\end{array}$ & $\begin{array}{c}53.24639 \\
1 \\
50.72706 \\
8 \\
\end{array}$ & $\begin{array}{l}53.246511 \\
50.727095\end{array}$ & $\begin{array}{l}53.246691 \\
50.727268\end{array}$ & $\begin{array}{c}53.2469 \\
50.72708 \\
2\end{array}$ & $\begin{array}{c}53.24697 \\
8 \\
50.72708 \\
5 \\
\end{array}$ & $\begin{array}{l}53.247161 \\
50.727068\end{array}$ & $\begin{array}{l}53.247246 \\
50.726946\end{array}$ & $\begin{array}{l}53.247611 \\
50.726826\end{array}$ \\
\hline $\begin{array}{l}\text { Total } \\
\text { biomass, } \\
\text { t/ha }\end{array}$ & 6.15 & 9.84 & 31.71 & 52.48 & 31.56 & 51.54 & 9.56 & 13.48 & 47.57 \\
\hline
\end{tabular}


Table 2. Crop structure: field 2, winter wheat + winter vetch, summary

\begin{tabular}{|c|c|c|c|c|c|c|c|c|c|}
\hline \multirow[t]{2}{*}{ Indicators } & \multicolumn{9}{|c|}{ Markers } \\
\hline & 1 & 2 & 3 & 4 & 5 & 6 & 7 & 8 & 9 \\
\hline $\begin{array}{l}\text { NDVI from } \\
\text { May } 19\end{array}$ & & 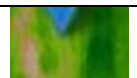 & 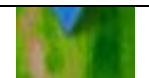 & 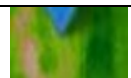 & 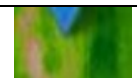 & 4 & 7 & 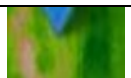 & 4 \\
\hline $\begin{array}{l}\text { (tillering } \\
\text { stage of } \\
\text { winter } \\
\text { wheat) }\end{array}$ & $\begin{array}{c}0.276 / 0.2 \\
5\end{array}$ & $\begin{array}{c}0.276 / 0.2 \\
5\end{array}$ & $0.276 / 0.25$ & $\begin{array}{c}0.276 / 0.2 \\
5\end{array}$ & $\begin{array}{c}0.276 / 0.2 \\
5\end{array}$ & $\begin{array}{c}0.276 / 0.2 \\
5\end{array}$ & $\begin{array}{c}0.276 / 0.2 \\
5\end{array}$ & $\begin{array}{c}0.276 / 0.2 \\
5\end{array}$ & $\begin{array}{c}0.276 / 0.2 \\
5\end{array}$ \\
\hline $\begin{array}{l}\text { NDVI from } \\
\text { June } 14\end{array}$ & & 5 & & & & & & & \\
\hline $\begin{array}{l}\text { (bloom } \\
\text { stage of } \\
\text { winter } \\
\text { wheat) }\end{array}$ & $0.149 / 0.1$ & $0.149 / 0.1$ & $0.149 / 0.1$ & $0.149 / 0.1$ & $0.149 / 0.1$ & $0.149 / 0.1$ & $0.149 / 0.1$ & $0.149 / 0.1$ & $0.149 / 0.1$ \\
\hline $\begin{array}{l}\text { NDVI from } \\
\text { June } 25\end{array}$ & & & & & & & & & \\
\hline $\begin{array}{l}\text { (milk stage } \\
\text { of winter } \\
\text { wheat) }\end{array}$ & $0.198 / 0.1$ & $0.198 / 0.1$ & $0.198 / 0.1$ & $0.198 / 0.1$ & $0.198 / 0.1$ & $0.198 / 0.1$ & $0.198 / 0.1$ & $0.198 / 0.1$ & $0.198 / 0.1$ \\
\hline $\begin{array}{l}\text { Number of } \\
\text { grains per } \\
\text { ear, } \\
\text { pcs./mass } \\
\text { of } 1000 \\
\text { grains, g }\end{array}$ & $35 / 41.43$ & $35 / 41.43$ & $35 / 41.43$ & $35 / 41.43$ & $35 / 41.43$ & $35 / 41.43$ & $35 / 41.43$ & $35 / 41.43$ & $35 / 41.43$ \\
\hline $\begin{array}{l}\text { Biomass, } \\
\text { grains, } \mathrm{t} / \mathrm{ha}\end{array}$ & 2.22 & 2.22 & 2.22 & 2.22 & 2.22 & 2.22 & 2.22 & 2.22 & 2.22 \\
\hline $\begin{array}{l}\text { Biomass, } \\
\text { total, t/ha }\end{array}$ & 4.75 & 4.75 & 4.75 & 4.75 & 4.75 & 4.75 & 4.75 & 4.75 & 4.75 \\
\hline $\begin{array}{l}\text { Coordinate } \\
\text { s } \\
\text { WGS84 }\end{array}$ & $\begin{array}{c}53.24638 \\
9 \\
50.7275\end{array}$ & $\begin{array}{c}53.24638 \\
9 \\
50.7275\end{array}$ & $\begin{array}{c}53.246389 \\
50.7275\end{array}$ & $\begin{array}{c}53.24638 \\
9 \\
50.7275\end{array}$ & $\begin{array}{c}53.24638 \\
9 \\
50.7275\end{array}$ & $\begin{array}{c}53.24638 \\
9 \\
50.7275\end{array}$ & $\begin{array}{c}53.24638 \\
9 \\
50.7275\end{array}$ & $\begin{array}{c}53.24638 \\
9 \\
50.7275\end{array}$ & $\begin{array}{c}53.24638 \\
9 \\
50.7275\end{array}$ \\
\hline
\end{tabular}

Table 3. Marker 6, field 4, spring hard wheat + barley + peas, with the predominance of weeds over crop plants, 06/25/2018

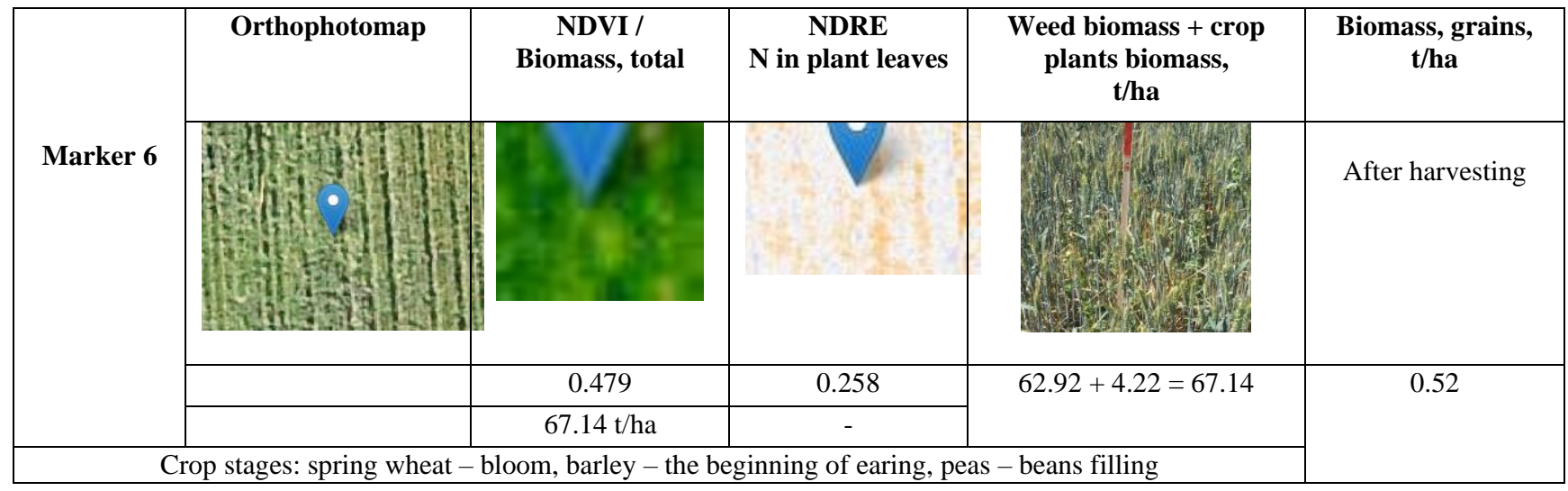


Thus, the highest correlation coefficient between NDVI and the grain yield of winter wheat was found in the milk stage of winter wheat $(r=0.82)$.

In 2019 , it is necessary to conduct a multispectral survey of winter wheat crops at the beginning of the milky-wax stage. We used the same method for digital monitoring of the remaining fields of polygon 2: field 1 - winter wheat; field 3 - barley; field 4 - spring hard wheat + barley + peas.

The calculation of the correlation coefficients between the NDVI and the physical indicators of biomass, total and grain biomass, showed that the greatest correlation in field 1 was also noted in the milky stage of winter wheat (with grain biomass, $r=0.36$ ); in the field 3 - in the phase the beginning of barley earing (with the biomass of grain, $r=0.97$ ).

On the field 4 on the date of June 25, the spring hard wheat bloom and the beginning of the barley earing, a negative correlation was obtained between the NDVI and total biomass $(\mathrm{r}=-0.63)$ and grain biomass $(\mathrm{r}=-0.59)$. Negative correlation coefficients were obtained because of markers $3,6,7$, and 8 , which showed a significant predominance of weed biomass over plant biomass.

Table 3 presents the different vegetation indexes for marker 6 of field 4 (spring hard wheat + barley + peas) on the date of June 25 (bloom of spring wheat, beginning of barley earing, pea beans filling).

Comparison of several vegetation indexes with field statistics of a specific plot of a field on a certain date of digital monitoring provides a unique opportunity to establish fundamental patterns, as well as to reveal a significant high correlation between relative index coefficients and real physical parameters of agrophytocenosis indicators like, for example, potential yield. The solution of this issue depends on the accumulation of a long-term database on soil-climatic zones, cultures and vegetation stages of crops [10].

Thus, the research conducted in 2018 revealed that the stated main goal to develop a digital monitoring methodology for agro-ecosystem indicators based on space and unmanned technologies with the conversion of the results of various types of digital aerial photography into real physical parameters of agrophytocenosis indicators is solvable.

It is necessary to continue accumulating the database as the basis for developing a digital platform for on-line conversion of vegetation indexes into specific physical parameters of the main indicators of single-species and poly-species agrophytocenosis for different crops and vegetation stages in these soil and climatic conditions in 2019 field season.

According to the results of 2018, the greatest correlation between the NDVI and the grain yield for winter and spring cereal crops was revealed in the milk stage (up to $r=0.82$ ).

We also revealed the main optimal phases for the development of grain crops for digital monitoring: tillering; booting; bloom; the beginning of milk-wax stage.

We need to expand the range of learning crops with the following species: tilled crops (sunflower, grain maize), grain legumes (chickpea, lentil, soybeans, mung bean) and cruciferous (mustard, rape, oilseed radish).

\section{Conclusion}

The full analysis of the obtained digital (multispectral and thermal imaging, orthophoto, photo and video, as well as nitrogen content indexes and others) and field statistics can provide significant results to identify the fundamental patterns of functioning of single-species and poly-species crops in the framework of global climate changes, including increased climate aridity.

\section{References}

1. The national program "Digital Economy of the Russian Federation" Retrieved from: http://government.ru/rugovclassifier/614/events/

2. The concept of scientific and technological development of digital agriculture "Digital Agriculture” Retrieved from: http://www.viapi.ru/ download/2018/Цифровое $\% 20$ сельское $\% 20$ хозяйс TBO.pdf

3. R.R. Fakhrutdinov, N.A. Baryshnikov, S.A. Guseva, Unmanned technology in agriculture - the prospects and relevance in the market Retrieved from: https://docplayer.ru/64559340-Oblasti-primeneniyabpla.html

4. R.R. Fakhrutdinov, N.A. Baryshnikov, S.A. Guseva, Experience of using multispectral photography survey in agriculture Retrieved from: https://ssau.ru/pagefiles/final\%20002\%20web.pdf

5. A.S. Cherepanov, E.G. Druzhinina, Spectral properties of plants and vegetation indexes GeoMatica 3, (2009)

6. F.V. Eroshenko, S.A. Bartalev, I.G. Storchak, D.Y. Plotnikov, Possibilities of remote evaluation of winter wheat yields based on the vegetative index of the photosynthetic potential Modern probl. of remote sensing of the Earth from space 13(4), (2016)

7. L.A. Sladkikh, M.G. Zakhvatov, E.I. Saprykin, E.Y. Sakharova, Technology for monitoring the status of crops according to Earth remote sensing in the south of Western Siberia GeoMatica 2, (2016)

8. K.I. Zubkova, T.G. Kurevleva, L.I. Permitina, Estimation of the error in calculating NDVI using empirical methods for taking into account the influence of the atmosphere Rocket and space instrument-making and information systems 3(2), (2016)

9. AgroGIS. User's manual Retrieved from: https://gis2.prom.aero

10. Y.V. Osorgin, O.N. Osorgina, Agroecological assessment of agricultural crops and their place in the composition of the designed crop rotations Innovation area 1, (2016) 